\title{
Effect of GIS parameters on modelling runoff from river basin. The case study of catchment in the Puck District
}

\author{
Dominika Kalinowska ${ }^{1, *}$, Pawet Wielgat ${ }^{1}$, Tomasz Kolerski ${ }^{1}$, and Piotr Zima ${ }^{1}$ \\ ${ }^{1}$ Department of Hydraulic Engineering, Gdansk University of Technology, Gdansk, Poland
}

\begin{abstract}
The study was preceded to check the impact of the adopted digital elevation model resolution on the determination of catchment parameters and the further influence of the received information on calculations related to the hydrograph at the closing point of the basin after a synthetic 100-year precipitation episode. The study area are river basins located in the Puck commune convoying water directly to the Puck Bay. These studies allowed the formulation of the basic assumptions for the research project (in short called WaterPuck) supported by the National Centre for Research and Development.
\end{abstract}

\section{Introduction}

The catchment's response to atmospheric precipitation is determined by many factors, including landform $[1,2]$. The basin delimitation depend on the direction of exposure of the sloping lands (aspect) and orientation of analyzed area and lead to basic geographic unit, a watershed, which is the limited space from which all the water is collected and drains surface water to a common point - the receiver (e.g. a river, a reservoir). The size of the basin has a direct impact on the volume of collected water, which need to be managed according to the local requirements. It seems difficult or even impossible to determine experimentally in which direction rainwater flows from each part of the analyzed area. Catchment boundaries are estimated based on topographic maps or a digital elevation model (DEM). In both cases, the results obtained depend on the accuracy of the input material and the simplifications adopted by the person or program processing the topographic information. Accuracy problems may occur while maps with a large scale or too low resolution of the digital elevation model is analyzed. It could be additionally hampered by employing an approximate approach to delineating the catchment boundaries.

The outflow from the basin is unsteady due to number of external inputs which sometimes may cause the flow to be characterized by rapid variability in time. From the flood hazard point of view, the most dangerous situation is overlapping flood surges originating from several subbasins in time and space [3]. The shape of the surface runoff hydrograph is determined, among others, by concentration time. It is a time required to describe the outflow delay from individual sub-basins. By definition this is the time after which the water from the most hydraulically advantageous point will flow down to the point closing the catchment. The calculation formulas use the lengths of the surface runoff lines and slopes for individual subbasins - these are further parameters resulting directly from the assumed altitude elevation mapping.

In the era of digitization and the multitude of available data, a large part of the work is improved by GIS tools [4-8]. In this paper, the calculation were made by adopting Soil and Water Assessment Tool (SWAT) software [9-11] used as a plug-in for the Q-GIS program (QSWAT). QSWAT uses Terrain Analysis Using Digital Elevation Models (TauDEMs) for watershed delineation. TauDEM provides a suite of programs to perform various geoprocessing functions [12-14]. In the first steps, the user defines how many cells of the numerical terrain model per square kilometer will be used for further pro-cesses. The preliminary delineation of the catchment boundaries is based on local linear hollows accepted as a river net-work [15]. The higher density of DEM cells included, the more streams are visible, and thus the more subbasins will be designated (each stream is assigned its own subbasins). The adoption of other subbasin borders will also affect local slope be-cause the slope determined for each calculation cell is ultimately averaged as a slope corresponding to the dedicated subbasin. The use of GIS tools allows for a large detailing and fragmentation of the hydrographic division, which will affect the outflow model from the basin.

The study was preceded to check the impact of the adopted DEM resolution on the determination of catchment parameters and the further influence of the received information on calculations related to the flow rate at the closing point of the basin after a synthetic 100 -year precipitation episode (probability of exceeding $p=1 \%)$. Calculations were made for two digital elevation models: (1) CODGiK (Polish Central Centre for Geodetic and Cartographic Documentation) and (2) DEM provided by the European Environment Agency. The study area are river basins located in the Puck commune convoying water directly to the Puck Bay.

\footnotetext{
* Corresponding author: domszawu@pg.edu.pl
} 
These studies allowed the formulation of the basic assumptions for the research project (in short called WaterPuck) supported by the National Centre for Research and Development within the BIOSTRATEG III program No. BIOSTRATEG3/343927/3/ $\mathrm{NCBR} / 2017$. Under this program, a system to calculate the maximum allowable amount of fertilizers to be used on fields, together with the determination of their impact on the environment of the Baltic Sea in the area of the Puck Bay will be created.

GIS technology and data analysis is very useful for hydro-logical modelling and determination of the uncontrolled basin outflow. Nowadays, through developed surveying tools including laser scanning (LIDAR) or photogrammetric image processing high accuracy digital elevation model can be generate easily [16-19]. For large watersheds though is still hampered by computing power. In the paper hydrologic rain-fallrunoff model was implemented to catchments in Puck region by using three DEM models with resolution $50 \times 50 \mathrm{~m}, 10 \times 10 \mathrm{~m}$ and $1 \times 1 \mathrm{~m}$. In addition the threshold parameter of minimum basin area was tested. Hydrologic model was fed with synthetic rainfall and real storm observed in July 2018.

\section{Area of study}

The study are concerns Puck Bay, where surface water flows from agricultural areas of the Puck District (Poland, Pomeranian Voivodship) (Fig. 1). This area is part of the Kashubian Coastland and includes Kepa Pucka together with two ice-marginal valleys: Plutnica Valley and Kashubian Valley. It is a young glacial area with a varied sculpture characterized by high denivelation (from -0.5 to $113.5 \mathrm{~m}$ above sea level) and cut by smaller valleys with steep slopes [20]. The bottoms of the valleys are river beds (e.g. Gizdebka River, Bladzikowski Creek). The geological structure consists of fluvioglacial deposits, mainly sands and gravels interlaced with clays. In terms of land use, we distinguish mainly two forms: agricultural and forest areas.

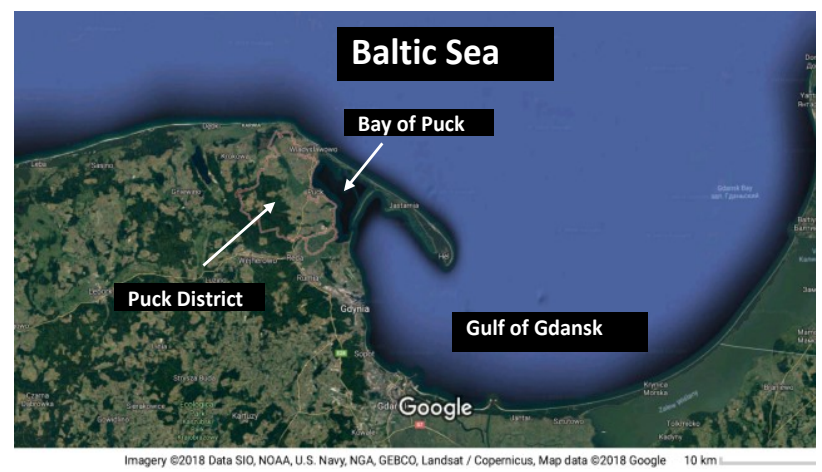

Fig. 1. Map of the study area (source: Google Maps, accessed 10 June 2018).

\section{Methodology and materials}

Data form laser scanning were obtained from Central Documentation Centre of Geodesy and Cartography in War-saw. The data were used to generating DEM with variable resections $(1,5$ and $10 \mathrm{~m}$ raster) - Fig. 3. Basin areas, rivers lengths and terrain denivelation were automatically obtained by using SWAT model. In calculations the threshold parameter for minimum basin area was tested using 1, 5 and $10 \mathrm{~km}^{2}$ (Fig. 4).

Soil types and land use was determined on the base of soil maps obtained from Marshal's Office of Pomeranian Voivodship. The maps were used to establish the soil groups based on the surface soils. Land use was also determined on the soil maps however to make the analysis less dependent on this parameter, only four types of land development was used in the study, i.e. forestland, meadow, cultivated agricultural land (row crops), residential (average lot size $1 / 4$ acre) and fully developed urban areas. All above information were used to determine runoff curve numbers $(\mathrm{CN})$ for average watershed condition [21, 22].

Hydrological calculations were proceeded for all combinations of DEM accuracies and minimum basin area. Model input was the $1 \%$ synthetic precipitation with duration of 60 minutes. Various methods for determining synthetic rain are used [23]. The rainfall time distribution was specified according to DVWK formula as shown in Fig. 2. Real precipitation measured in night from July $17^{\text {th }}$ to $18^{\text {th }} 2018$ was also used to compare model results with real data. Water surface elevation is surveyed on gauging stations located on each river's outlet to the Puck Bay. The discharge is calculated from the rating curve established for each station.

Hydrological modelling System HEC HMS was used to in this study to evaluate rainfall-runoff modelling $[24,25]$. The software was developed by U.S. Army Corps of Engineers and provided on the Corps' web page as an open access engineering tool. All required data were generated by using used as a plug-in for the QGIS program.

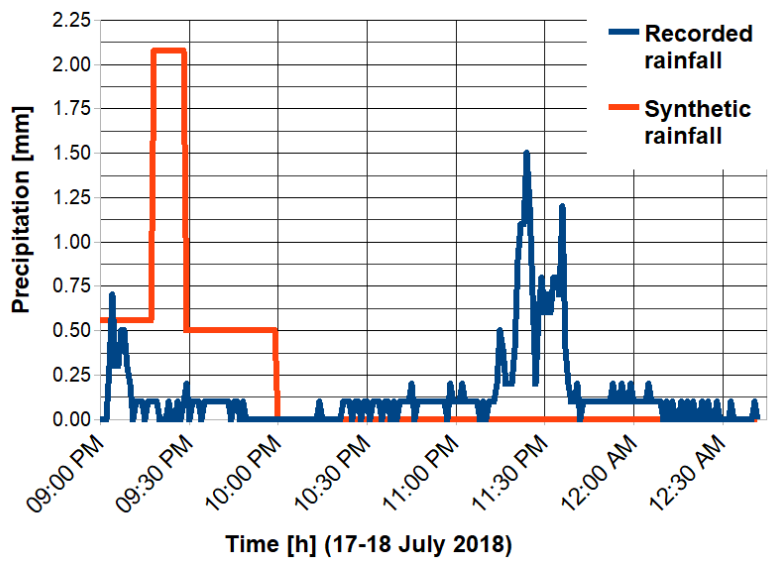

Fig. 2. Synthetic and recorded rainfall used in simulations. 
It is worth emphasizing the long time needed to generate a high resolution DEM grid. In the case of the tested catchment area, it was from 2 hours for $50 \times 50 \mathrm{~m}$ resolution to about 72 hours of continuous virtual machine operation for $1 \times 1 \mathrm{~m}$ resolution. For DEM with the lowest resolution, basins were generated in no more than half an hour, while for the DEM with a resolution of $1 \times 1 \mathrm{~m}$ it was about 36 hours. During the generation of these grids, the resources of the PIONIER cloud network service with 3 virtual machines (6 CPUs, 8 GB RAM) were used.
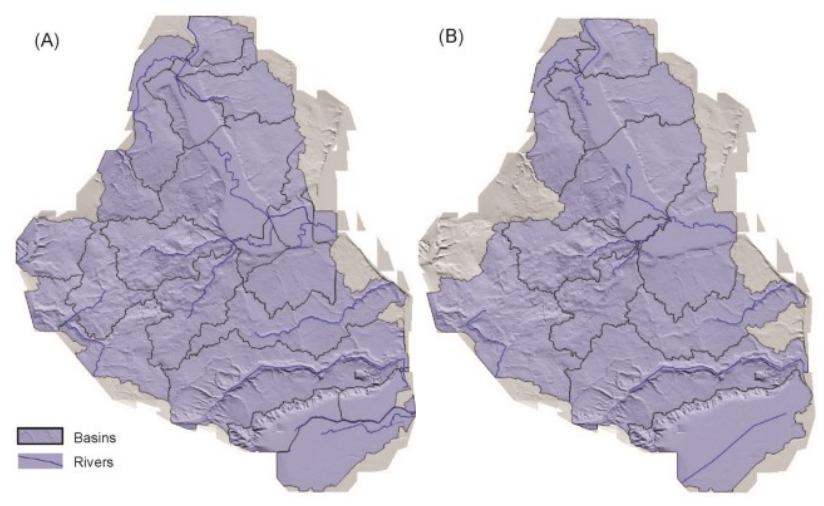

Fig. 3. Subasins distribution In Puck district for using DEM with (A) high accuracy $(1 \times 1 \mathrm{~m})$ and (B) low accuracy (10x10 m) (source: SWAT).
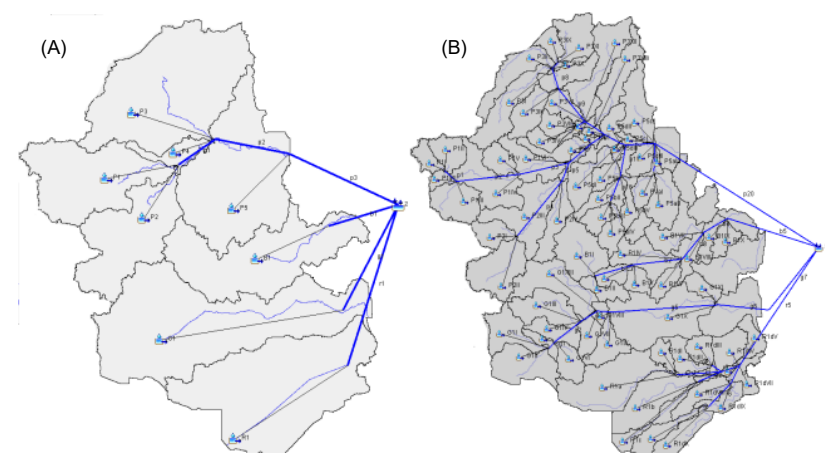

Fig. 4. Basin model and river network in HEC HMS model for low (A) and high (B) accuracy catchments (source: HECHMS).

\section{Results and discussion}

As a result of hydrological simulations, a total outflow was obtained in the characteristic cross-sections of the prepared catchment models. These values for each scenario are similar. The results in the form of maximum flow rate (peak dis-charge), time of its occurrence and total volume of water are presented in Tables I - IV and Figures 5-6.

Differences in the results obtained are related to the level of details included in individual models. When the DEM resolution is low many elements, i.e. road embankments and levees are invisible. In the case of high DEM resolution, very ac-curate DEM takes into account these details and fundamentally changes the subbasins delimitation along the crown of linear objects (Fig. 7).
Table 1. Discharge to Bay of Puck synthetic rainfall.

\begin{tabular}{|l|c|c|c|c|c|}
\hline \multicolumn{5}{|c|}{ Probability 1\%, duration 60 minutes } \\
\hline $\begin{array}{l}\text { Resolution of } \\
\left.\text { DEM [m }{ }^{2}\right]\end{array}$ & 1 & 100 & 100 & 100 & 2500 \\
\hline $\begin{array}{l}\text { Minimal area } \\
\text { subbasin }\left[\mathrm{km}^{2}\right]\end{array}$ & 5 & 1 & 5 & 10 & 5 \\
\hline $\begin{array}{l}\text { Time of peak } \\
\text { discharge } \\
{[\mathrm{HH}: \mathrm{MM}]}\end{array}$ & $4: 29$ & $3: 23$ & $4: 41$ & $11: 46$ & $3: 33$ \\
\hline $\begin{array}{l}\text { Peak discharge } \\
{\left[\mathrm{m}^{3} / \mathrm{s}\right]}\end{array}$ & 83,7 & 84,5 & 61,5 & 22,9 & 97,7 \\
\hline $\begin{array}{l}\text { Total volume } \\
{\left[1000 \mathrm{~m}^{3}\right]}\end{array}$ & 1363,1 & 1343,0 & 1303,6 & 1301,6 & 1272,8 \\
\hline
\end{tabular}

Table 2. Discharge to Bay of Puck recorded rainfall.

\begin{tabular}{|l|c|c|c|c|c|}
\hline \multicolumn{7}{|c|}{ Recorded rainfall 7/17/2018 } \\
\hline $\begin{array}{l}\text { Resolution of } \\
\text { DEM [m²] }\end{array}$ & 1 & 100 & 100 & 100 & 2500 \\
\hline $\begin{array}{l}\text { Minimal area } \\
\left.\text { subbasin [km }{ }^{2}\right]\end{array}$ & 5 & 1 & 5 & 10 & 5 \\
\hline $\begin{array}{l}\text { Time of peak } \\
\text { discharge } \\
{[\mathrm{HH}: \mathrm{MM}]}\end{array}$ & $6: 36$ & $5: 36$ & $6: 26$ & $14: 21$ & $5: 47$ \\
\hline $\begin{array}{l}\text { Peak discharge } \\
{\left[\mathrm{m}^{3} / \mathrm{s}\right]}\end{array}$ & 8,0 & 7,8 & 6,5 & 2,2 & 9,9 \\
\hline $\begin{array}{l}\text { Total volume } \\
{\left[1000 \mathrm{~m}^{3}\right]}\end{array}$ & 138,6 & 142,1 & 131,4 & 131 & 130,4 \\
\hline
\end{tabular}

Table 3. Gizdebka river discharge recorded rainfall.

\begin{tabular}{|l|c|c|c|c|c|}
\hline \multicolumn{7}{|c|}{ Recorded rainfall 7/17/2018 } \\
\hline $\begin{array}{l}\text { Resolution of } \\
\text { DEM [m²] }\end{array}$ & 1 & 100 & 100 & 100 & 2500 \\
\hline $\begin{array}{l}\text { Minimal area } \\
\text { subbasin }\left[\mathrm{km}^{2}\right]\end{array}$ & 5 & 1 & 5 & 10 & 5 \\
\hline $\begin{array}{l}\text { Time of peak } \\
\text { discharge } \\
{[\mathrm{HH}: \mathrm{MM}]}\end{array}$ & $6: 21$ & $7: 46$ & $7: 58$ & $20: 35$ & $6: 25$ \\
\hline $\begin{array}{l}\text { Peak discharge } \\
{\left[\mathrm{m}^{3} / \mathrm{s}\right]}\end{array}$ & 2,2 & 3,3 & 1,5 & 0,4 & 2,0 \\
\hline $\begin{array}{l}\text { Total volume } \\
{\left[1000 \mathrm{~m}^{3}\right]}\end{array}$ & 37,1 & 35,9 & 36 & 34,7 & 33,4 \\
\hline
\end{tabular}

Table 4. Gizdebka river discharge synthetic rainfall.

\begin{tabular}{|l|c|c|c|c|c|}
\hline \multicolumn{7}{|c|}{ Probability 1\%, duration 60 minutes } \\
\hline $\begin{array}{l}\text { Resolution of } \\
\left.\text { DEM [m }{ }^{2}\right]\end{array}$ & 1 & 100 & 100 & 100 & 2500 \\
\hline $\begin{array}{l}\text { Minimal area } \\
\text { subbasin }\left[\mathrm{km}^{2}\right]\end{array}$ & 5 & 1 & 5 & 10 & 5 \\
\hline $\begin{array}{l}\text { Time of peak } \\
\text { discharge } \\
{[\mathrm{HH}: \mathrm{MM}]}\end{array}$ & $4: 06$ & $7: 33$ & $5: 42$ & $18: 24$ & $4: 09$ \\
\hline $\begin{array}{l}\text { Peak discharge } \\
{\left[\mathrm{m}^{3} / \mathrm{s}\right]}\end{array}$ & 23,6 & 36,0 & 15,7 & 4,5 & 20,9 \\
\hline $\begin{array}{l}\text { Total volume } \\
{\left[1000 \mathrm{~m}^{3}\right]}\end{array}$ & 389,4 & 376,7 & 377,2 & 362,5 & 350,3 \\
\hline
\end{tabular}


(A)

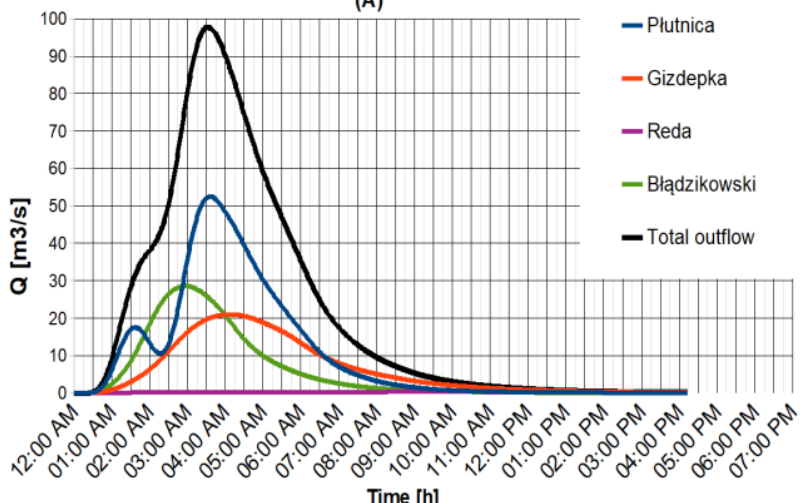

(B)

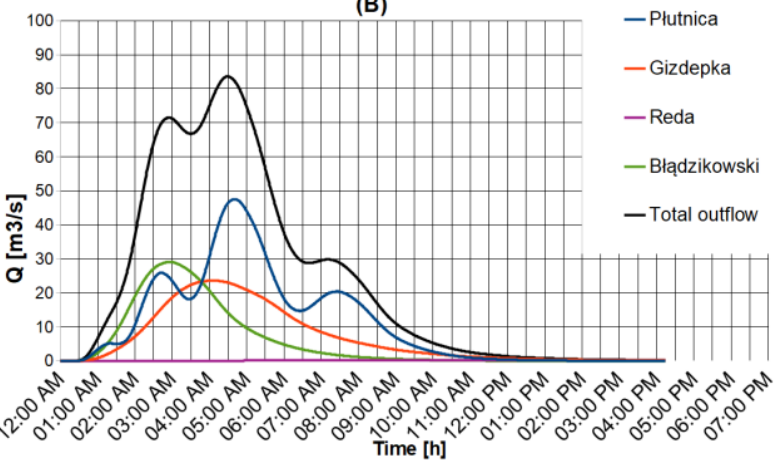

Fig. 5. Simulated hydrographs from Puck District (for precipitation with a probability of exceeding $p=1 \%$ and rain duration $60 \mathrm{~min}$ ) on the outflow to the Puck Bay for variable digital terrain model: (A) $50 \mathrm{~m} 2$ and (B) $1 \mathrm{~m} 2$.

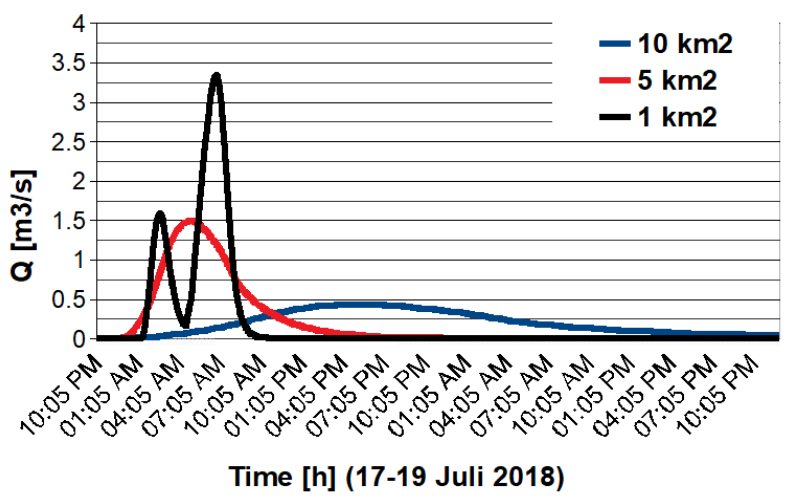

Fig. 6. Simulated water discharge at the outlet of the Gizdebka River to the Puck Bay, for rainfall recorded on June 17th 18th, 2018.

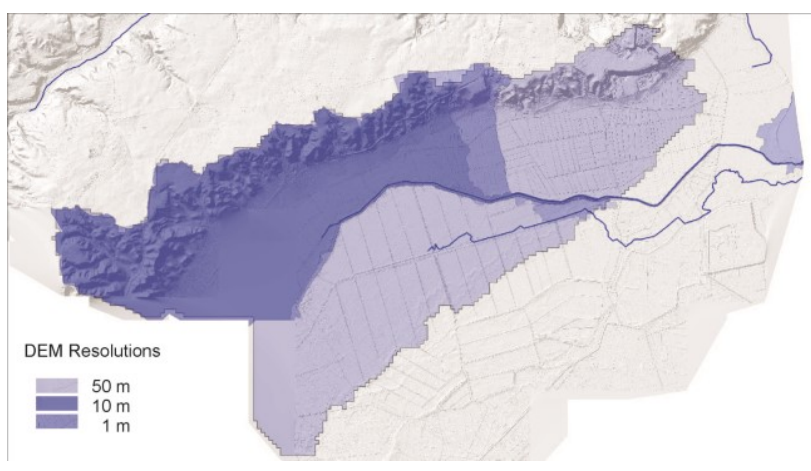

Fig. 7. Differences in Reda catchment for variable digital terrain model $-1,10$ and $50 \mathrm{~m}^{2}$.

\section{Summary and conclusion}

Base on the study following conclusions could be stated:

1) Resolution of the digital terrain model must be properly chosen to avoid following problems:

a) too high resolution of the DEM model i.e. very detail terrain reconstruction will false watershed divides. This is usually caused by linear structures: berms, irrigation channels, embankment dikes and others. This will cause not realistic lag time for the sub-basins.

b) too low resolution $(50 \times 50 \mathrm{~m})$ will affect missing small streams and irrigation channels and in consequence the river network will be not be completed. Sub-basins are coarse with large area not reflecting the reality.

c) the DEM resolution affects the basin shape in the downstream reach, close to the outlet. It is caused by the direct sea basins which areas changes with model resolutions.

2) The threshold parameter of minimum basin size has significant impact on the outflow formation form the watershed. The volume of the surface outflow similar, but the peak discharge varies significantly. Also the time to peak value is different for variable minimum basins parameters, in such a way that the closed to reality is division to average sub-basins $\left(5 \mathrm{~km}^{2}\right)$. In that case the peak discharge calculated in the Gizdebka River was in rage of $1.5 \mathrm{~mm}^{3} / \mathrm{s}$, very close to the measured water outflow from the survey.

Online references will be linked to their original source, only if possible. To enable this linking extra care should be taken when preparing reference lists.

\section{Acknowledgment}

The authors are grateful to CI TASK (Centre of Informatics - Tricity Academic Supercomputer \& network) for granting access to the computing infrastructure built in the projects No. POIG.02.03.0000-028/08 "PLATON - Science Services Platform" and No. POIG.02.03.00-00-110/13 "Deploying highavailability, critical services in Metropolitan Area Networks (MAN-HA)" 
These studies allowed the formulation of the basic assumptions for the research project (in short called WaterPuck) supported by the National Centre for Research and Development within the BIOSTRATEG III program No. BIOSTRATEG3/ $343927 / 3 / \mathrm{NCBR} / 2017$. Under this program, a system to calculate the maximum allowable amount of fertilizers to be used on fields, together with the determination of their impact on the environment of the Baltic Sea in the area of the Puck Bay will be created.

\section{References}

1. D.R. Maidment, Handbook of hydrology, McGrawHill (1992)

2. S. Eslamian, Handbook of engineering hydrology: fundamentals and applications, CRC Press, Taylor and Francis NY (2014)

3. W. Szpakowski and M. Szydłowski, Evaluating the Catastrophic Rainfall of 14 July 2016 in the Catchment Basin of the Urbanized Strzyza Stream in Gdańsk, Polish Journal of Environmental Studies, 27, 2, pp. 861-869, (2018). DOI: $10.15244 /$ pjoes/75962

4. M. Szydłowski, et al., Stormwater and snowmelt runoff storage control and flash flood hazard forecasting in the urbanized coastal basin, in Proc. of 14th International Symposium Water Management and Hydraulic Engineering WMHE 2015, pp. 141-150 (2015)

5. P. Wielgat and P. Zima, Analysis of the impact of the planned sewage discharge from the 'North' Power Plant on the Vistula water quality, in Proc. of 16th International Multidisciplinary Scientific GeoConference SGEM 2016, book 3, vol. 3, pp. 1926 (2016). DOI: 10.5593/SGEM2016/HB33/S02.003

6. P. Zima, Modeling of the Two-Dimensional Flow Caused by Sea Conditions and Wind Stresses on the Example of Dead Vistula, Polish Maritime Research, 25, s1, pp. 166-171 (2018). DOI: 10.247/pomr-2018-0038

7. T. Kolerski, Modeling of ice phenomena in the mouth of the Vistula River, Acta Geophysica, 62, 893-914 (2014). DOI:10.2478/s11600-014-0213-x

8. T. Kolerski, Ice cover progression due to flow regulation at the Wloclawek dam, Acta Scientiarum Polonorum. Formatio Circumiectus, 14, 229-240 (2015)

9. J.G. Arnold, N. Fohrer, SWAT2000: Current capabilities and research opportunities in applied watershed modelling, Hydrological Processes, 19, 3, pp. 563-572, (2005). DOI: 10.1002/hyp.5611
10. J.G. Arnold, et al., Soil and Water Assessment Tool input/output file documentation: Version 2012, Texas Water Resources Institute, TR-439, (2012)

11. R. Srinivasan, et al., Large area hydrologic modeling and assessment part II: model application, Journal of the American Water Resources Association, 34 (1), pp. 91-101, (1998). DOI: 10.1111/j.1752-1688.1998.tb05962.x

12. T.K.Tesfa, et al., Extraction of hydrological proximity measures from DEMs using parallel processing, Environmental Modelling \& Software, 26 (12), pp. 1696-1709, (2011). DOI: 10.1016/j.envsoft.2011. 07.018

13. J.P. Wilson, Digital terrain modeling, Geomorphology, 137, 1, pp. 107-121 (2012). DOI: 10.1016/j.geomorph.2011.03.012

14. Y.T. Dile, et al., Introducing a new open source GIS user interface for the SWAT model, Environmental Modelling \& Software, 85, pp. 129-138 (2016). DOI: $10.1016 /$ j.envsoft.2016.08.004

15. D.G. Tarboton, A new method for the determination of flow directions and upslope areas in grid digital elevation models, Water Resources Research, 33, 2, pp. 309-319 (1997). DOI: 10.1029/96WR03137

16. K. Bobkowska, A. Inglot, M. Mikusova, P. Tysiąc, Implementation of Spatial Information for Monitoring and Analysis of the Area Around the Port Using Laser Scanning Techniques, Polish Maritime Research, 24, S1, pp. 10-15 (2017). DOI: 10.1515/pomr-2017-0015

17. K. Bobkowska, A. Janowski, J. Szulwic, 3D modelling of cylindrical-shaped objects from LiDAR data - an assessment based on theoretical modelling and experimental data, Metrology and Measurement Systems, Vol. 25, issue 1, pp. 47-56, 2018. DOI: $10.24425 / 118156$

A. Inglot, P. Tysiąc, Airborne Laser Scanning Point Cloud Update by Used of the Terrestrial Laser Scanning and the Low-Level Aerial Photogrammetry, Proceedings - 2017 Baltic Geodetic Congress (Geomatics), BGC Geomatics 2017, pp. 34-38 (2017). DOI: 10.1109/ BGC.Geomatics.2017.75

18. J. Szulwic, P. Ziolkowski, A. Janowski, Combined Method of Surface Flow Measurement Using Terrestrial Laser Scanning and Synchronous Photogrammetry, Proceedings - 2017 Baltic Geodetic Congress (Geomatics), BGC Geomatics 2017, pp. 110-115 (2017). DOI: 10.1109/ BGC.Geomatics.2017.54

19. D. Potrykus, et al., Assessing groundwater vulnerability to pollution in the Puck region (denudation moraine upland) using vertical seepage 
method, E3S Web of Conferences. 44, 00147 (2018). DOI 10.1051/ e3sconf/20184400147

20. Jr.A.T. Hjelmfelt, Investigation of curve number procedure, Journal of Hydraulic Engineering, 117, pp. 725-737 (1991). DOI: 10.1061/(ASCE)07339429(1991)117:6(725)

21. SCS: National Engineering Handbook, Section 4: Hydrology, Soil Conservation Service, USDA, Washington, D.C. (2004)

22. K. Weinerowska-Bords, Development of Local IDFformula Using Controlled Random Search Method for Global Optimization, Acta Geophysica, 63, 1, pp 232-274, (2015). DOI 10.2478/s11600-014-0242-5

23. W. A. Scharffenberg and M. J. Fleming, Hydrologic Modeling System HEC - HMS User's Manual (2010)

24. HEC-HMS Technical Reference Manual, US Army Corps of Engineers Hydrologic Engineering Center, USA (2000) 